Primljen / Received: 10.7.2017. Ispravljen / Corrected: 31.1.2018. Prihvaćen / Accepted: 18.2.2018. Dostupno online / Available online: 10.5.2018.

\section{Analysis of financial indicators of EU co-funded wastewater collection and treatment projects in the Republic of Croatia}

Authors:

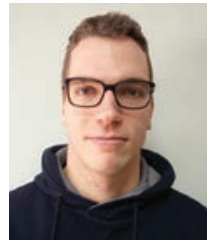

Igor Tadić, MCE Hidroing d.o.o. Osijek, Croatia igor.tadic@hidroing-os.hr

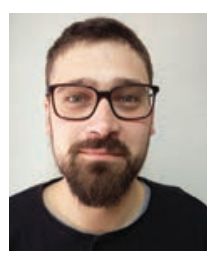

Branimir Barač, MCE

Hidroing d.o.o. Osijek, Croatia

branimir.barac@hidroing-os.hr

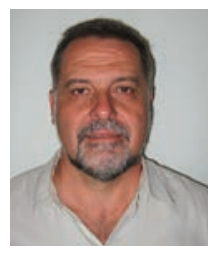

Zdenko Tadić, MCE

Hidroing d.o.o. Osijek, Croatia

zdenko.tadic@hidroing-os.hr

\section{Igor Tadič, Branimir Barač, Zdenko Tadić}

Analysis of financial indicators of EU co-funded wastewater collection and treatment projects in the Republic of Croatia

Preparation of EU co-funded wastewater infrastructure projects of substantial magnitude requires a holistic and multidisciplinary approach, from analysis of the existing input data, to optimisation of the size of agglomeration and evaluation of relevant technical solutions. Financial parameters of the project vary greatly depending on geographical differences of individual areas in the Republic of Croatia. Comparison of projects shows that, although basic financial parameters can be correlated, the underlying trends are subject to project location and background particularities.

Key words:

EU co-funding, project comparison, financial parameters of projects, geographical distinctions

Stručni rad

Igor Tadić, Branimir Barač, Zdenko Tadić

Analiza financijskih pokazatelja EU sufinanciranih projekata odvodnje i pročišćavanja otpadnih voda u Republici Hrvatskoj

Priprema EU sufinanciranih projekata u vodnokomunalnom sektoru je uobičajeno značajnog financijskog opsega te kao takva zahtijeva cjelovit i multidisciplinaran pristup: od analize postojećih ulaznih podataka, optimizacije obuhvata aglomeracija koje su predmet projekta do vrednovanja tehničkih rješenja koja se primjenjuju. Financijski parametri projekta značajno variraju ovisno o zemljopisnim razlikama u Republici Hrvatskoj. Usporedba projekata pokazala je da se osnovni financijski parametri mogu povezati, ali temeljni trendovi su ovisni o lokaciji projekta i pozadinskim utjecajima.

Ključne riječi:

EU sufinanciranje, usporedba projekata, financijski parametri projekta, zemljopisne razlike

Fachbericht

Igor Tadić, Branimir Barač, Zdenko Tadić

Analyse der Finanzindikatoren der durch die EU mitfinanzierten Abwasser- und Abwasserbehandlungsprojekte in der Republik Kroatien

Die Vorbereitung der durch die EU mitfinanzierten Projekte im Wasserversorgungssektor weist den üblichen bedeutenden Finanzumfang auf, und als solcher erfordert er einen umfassenden und multidisziplinären Ansatz: Analyse der vorhandenen Eingangsdaten, Optimierung des Umfangs der Agglomerationen, die Gegenstand des Projektes sind, bis zur Bewertung der technischen Lösungen, die angewendet werden. Die Finanzparameter des Projektes variieren erheblich, abhängig von den geografischen Unterschieden in der Republik Kroatien. Der Vergleich der Projekte zeigte, dass die grundlegenden Finanzparameter verknüpft werden können, aber die zugrunde liegenden Trends hängen vom Standort des Projektes und den Hintergrundeinflüssen ab.

Schlüsselwörter:

EU-Mitfinanzierung, Vergleich der Projekte, Finanzparameter des Projektes, geografische Unterschiede 


\section{Introduction}

The Republic of Croatia's accession to the European Union has activated the commitment of meeting requirements of the Urban Waste Water Directive (91/271 EEC) [1] and the Water Framework Directive (2000/60/EC) [2]. A key element of fulfilling the requirements relates to the construction of wastewater infrastructure, namely collectors/sewers and wastewater treatment plants, which will enable achievement of required connection rates and wastewater treatment levels, as related to agglomeration size and discharge zone.

The preparation of water sector infrastructure projects for EU funding is generally seen as a time-consuming endeavour. Numerous project development stages must be completed before actual start of work: feasibility study and environmental impact assessment, design work and permitting, application package and tender dossiers with associated procurement procedures. According to experience of the authors gained on a number of projects, the EU funded projects in water/ wastewater sector generally require, regardless of their size, a minimum of three years from the start of the feasibility study to the actual commencement of work (sometimes even up to 7-8 years). Additionally, throughout the project development, it is crucial to achieve uniformity across all project levels and at all stages to adhere to strict EU guidelines and to comply with procedures as set out by relevant national authorities.

Of course, the main reason for development of these projects is to obtain EU funding. Generally, projects tend to attract approximately $70 \%$ of EU funds, which is dependent on relevant cost-benefit analyses. The rest of the funding comes from national budget, Hrvatske vode (national governing body for all water related activities), and local component (end-beneficiary of the project or municipality concerned with the development). So, difficulties with project application notwithstanding, there is a strong interest for EU funding of these [3], usually quite costly, infrastructure projects.

In this paper, the authors provide an overview of basic input data that define the scope of the project. The main focus of the paper is on the comparison of financial parameters of the ongoing or fully developed projects, as a means for establishing broader project-development conclusions. Special attention is paid to geographical specificities across the Republic of Croatia which is divided into continental and coastal Croatia, since the projects are clearly quite diverse.

\section{Methods}

\subsection{Demand analysis}

The Demand Analysis is the first and often crucial step in project development. Its goal is to accurately quantify all important technical parameters of the project, both in its present state and throughout the project period (set at 30 years for water sector). It includes:
- Population analysis and demographic forecasts

- Water consumption analysis, with special attention given to distinct consumer categories (domestic, industrial or tourism consumption)

- Specific water consumptions

- Quantification of wastewater discharges

- Identification of target month/year for infrastructure loads

- Hydraulic and biological loads on WWTPs.

An accurately defined Demand Analysis is the prerequisite for a technically sound scope of investment measures.

\subsubsection{Continental Croatia}

The main trend in the Demand Analyses across continental Croatia is the decrease in population, naturally followed by decrease in water consumption. This is in line with national (and Eurostat) [4] demographic forecasts that are largely negative, aided by emerging trend of workforce emigration to other EU countries due to poor economic situation. An exemption is the wider Zagreb area, as well as the counties situated in northern Croatia (Varaždin and Međimurje counties to name a few) which still achieve solid economic indicators and are therefore less subject to workforce emigration. On the other hand, Slavonia and Baranja region, as well as Gorski Kotar and Lika, are the areas that are mostly affected by negative demographic trends.

The above mentioned trends should factor in heavily into Demand Analysis. A decrease in population and water consumption directly leads to:

- Negative forecasts throughout the project period, meaning that the target period for dimensioning is often at the very start of the project period

- Decrease in population and industry consumption directly leads to decrease in billed water consumption throughout the project period (which also forms the basis for billed wastewater discharges), which has very tangible effects on financial analysis of the project, namely combined price of water services and subsequent affordability issues.

The reversal of negative demographic and economic indicators exceeds by far the limits of a single Feasibility Study, and so no comments can be made in that regard. The main issue is the above mentioned problem of financial sustainability of the project.

Other than that, the Demand Analysis usually shows relatively clear elements: specific domestic consumption is generally seen to decrease (increase in water tariffs as a result of the project is also an important factor), with urban consumption of around $110-130 \mathrm{l} / \mathrm{c} / \mathrm{d}$ and rural consumption of around 80-100 l/c/d. The seasonality of consumption is only mildly represented. Several measurement campaigns showed an increase of around $20-25 \%$ in specific consumption comparing winter and summer patterns, mostly attributed to higher water consumption in the 
scope of activities not related to wastewater sector (irrigation etc.), which should be discarded at the dimensioning stage for wastewater systems.

\subsubsection{Coastal Croatia}

In contrast to continental Croatia, coastal Croatia shows a completely different set of general parameters in the Demand Analysis. The overarching element is the influence of tourism, which has a direct impact on demographic trends, economic landscape of the area, as well as on agglomeration loads. Main effects of tourism are:

- Continuous increase in overnights recorded in recent years points to a positive forecast throughout the project period, which can sometimes be difficult to assess. Significant positive trend in the number of tourist overnights often results in the target period for dimensioning at the very end or the project period, which could in turn lead to inquiries about justification of infrastructure usage in the beginning of the project period (for whom are we building the infrastructure, and who is to provide the cost recovery right now?)

- High variance in seasonal loads for both water and wastewater systems which needs to be accurately assessed and addressed in the design phase of the project through specific technical solutions (occasional system users that are active only in the summertime, but still require the infrastructure to be designed and constructed for the (very brief) period of their high loads).

\subsection{Agglomeration scope and financial analysis of the project}

During development of the Feasibility Study, agglomeration scope is often a point of contention between the project stakeholders. This conflict stems from a very broad set of criteria applied for agglomeration sizing, which can vary depending on the Study and its consultants. According to the definition given in the Urban Waste Water Treatment Directive [1] (and largely transposed into national legislation [5]), an agglomeration is defined as:an area where the population and/or economic activities are sufficiently concentrated for urban wastewater to be collected and conducted to an urban wastewater treatment plant or to a final discharge point. The definition of "sufficiently concentrated economic activities" is therefore subject to interpretation. The following criteria are usually applied when assessing agglomeration size:

- Investment cost $€$ / PE-or-user - a measure of achieving a sufficient ratio between the required investment and new number of users in the system. This criterion can be seen as a prerequisite to a "clean" CBA. General threshold applied was around 2,500 €/PE or user. This threshold is not a clear indicator of affordability calculation in the cost-benefit analysis (that is largely based on the operating costs), but is rather an indicator of investment depreciation throughout the project period.

- Operating cost $€ / P E-o r-u s e r / y e a r-a$ measure of achieving a sufficient ratio between the total projected operating costs and new number of users in the system. General

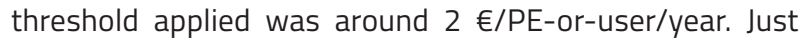
like the previous criterion, this one also tackles indicators on a per user basis, but is designed to (roughly) show the status of affordability of the project. The problem with this criterion is that it cannot be applied uniformly. One of the factors in affordability calculation is the monthly net average household income, which can vary greatly depending on the project location. Economically stronger area can probably "survive" higher incremental operating costs of the project. In that respect, this criterion can misjudge an optimum agglomeration size.

- Length of sewage / connection - a measure of achieving sufficient urban concentration to minimize over-investment so as to achieve minimum gains (low number of new connections). General threshold applied was around 35$40 \mathrm{~m}$ ' of all pipelines (collectors or transient systems) per connection.

- Distance of settlement to the centroid of the agglomeration - a measure of achieving sufficient cluster within the agglomeration. General threshold seen to be applied was $2,5 \mathrm{~km}$. The problem with this criterion is that it is entirely one-dimensional (and probably a bit harsh). It is entirely possible (and likely due to the nature of settlement development) that a larger settlement outside the $2,5 \mathrm{~km}$ radius can be seen as feasible for connection to the centroid of the agglomeration.

- Stakeholders input - a purely qualitative factor but sometimes the most important, stakeholders input is seen to be crucial for further development of the feasibility study. Sometimes it is seen as a positive contribution due to the more detailed knowledge of the project area by the end-beneficiary but - more often than not - it is detrimental due to requests for over-expansion of the agglomeration size which surely leads to problems later in the costbenefit analysis (first and foremost, affordability issues). It is important to properly and timely inform the endbeneficiary about implications of the agglomeration overexpansion, because this can greatly complicate the project development.

Financial analysis of the project stems directly from the following categories:

- Current financial capacity of the end-beneficiary, mostly in terms of the currently applied consumer tariffs (water and wastewater combined), as well as financial reserves to undertake a project of substantial size (due to relatively poor current state of water/wastewater infrastructure, almost any project can be seen as substantial by Croatian standards). Existing consumer tariffs are diverse 
throughout Croatia - they depend on a multitude of actors: number of consumers, share of tourism/industry consumers, existing infrastructure and the costs of maintenance, the need for more advanced treatments in water and wastewater sectors (depending on the location within Croatia), as well as on the management and staffing of the utility company.

- Investment scope of the project, namely investment and operating costs. Both of these categories impact heavily the financial analysis of the project - investment costs through the calculation of the EU grant and depreciation costs, and operating costs through increased consumer tariffs. It is especially important to accurately assess both of these in order to achieve financial sustainability.

- Ability of the project area to sustain the increased price of water/wastewater service which largely revolves around disposable net income of the average household (affordability threshold of $3 \%$ of an average monthly household budget).

In the following sections, an overview of several finished or ongoing projects in Croatia will be given in terms of project indicators revolving around agglomeration size, investment and operating costs, and total consumer tariffs. The projects stem from various consultants which enhances the differences between approaches to project development. The analysis will be given for continental and coastal Croatia, respectively.

\section{Results and discussion}

\subsection{Continental Croatia}

General overview and difficulties of this particular area have been outlined in Section 2.1.1. In the following section, an overview is given for 14 EU projects in continental Croatia at various stages of development. General data has been extracted for all these projects, excluding investments into water supply and reconstruction/ rehabilitation of the existing sewage network. Therefore, the scope of the projects has been exclusively oriented toward sewage extension (reflecting the proposed agglomeration size), wastewater treatment and additional auxiliary components of the project (supervision, equipment supply, technical assistance, and visibility), and excluding contingencies on the project. Continental Croatia has an underlying trend regarding the choice of treatment technology. All of the plants built, commissioned or planned are generally divided between the conventional activated sludge (CAS) technology and the sequence batch reactor (SBR) technology. Since those two wastewater treatment technologies offer similar investment and operating costs, there was almost no influence of the proposed technology on the above given results. Additionally, there is a general tendency of clustering the sewage treatment to bigger, centralized plants to minimize maintenance and operating costs, subsequently minimizing the number of plants as well. Also, this adds to a more uniform set of input data for the analysis given below, and so any outliers are interesting to observe. Two graphs are given below - one depicts the correlation between investment and operating costs while the other depicts the correlation between the net-present value of the project and the total consumer tariff (Figure 1).

The net present value (NPV) was calculated for a 30-year project period, assuming 3 years of works followed by 27 years of operational period. The discount rate was calculated at $4 \%$, in accordance with the methodology for infrastructure projects, as set forth by the Directorate General Regional Policy (DG REGIO). It should be noted that the NPV was calculated from a technical standpoint, factoring only discounted operating costs. No financial changes in the operating costs were taken into account (change in the price of electricity, change in wages for incremental staffing, etc.).

The total consumer tariff is given for the last year of the project period in the "with project" scenario. Incremental rise in the tariffs (project result) was deemed unfit because of various

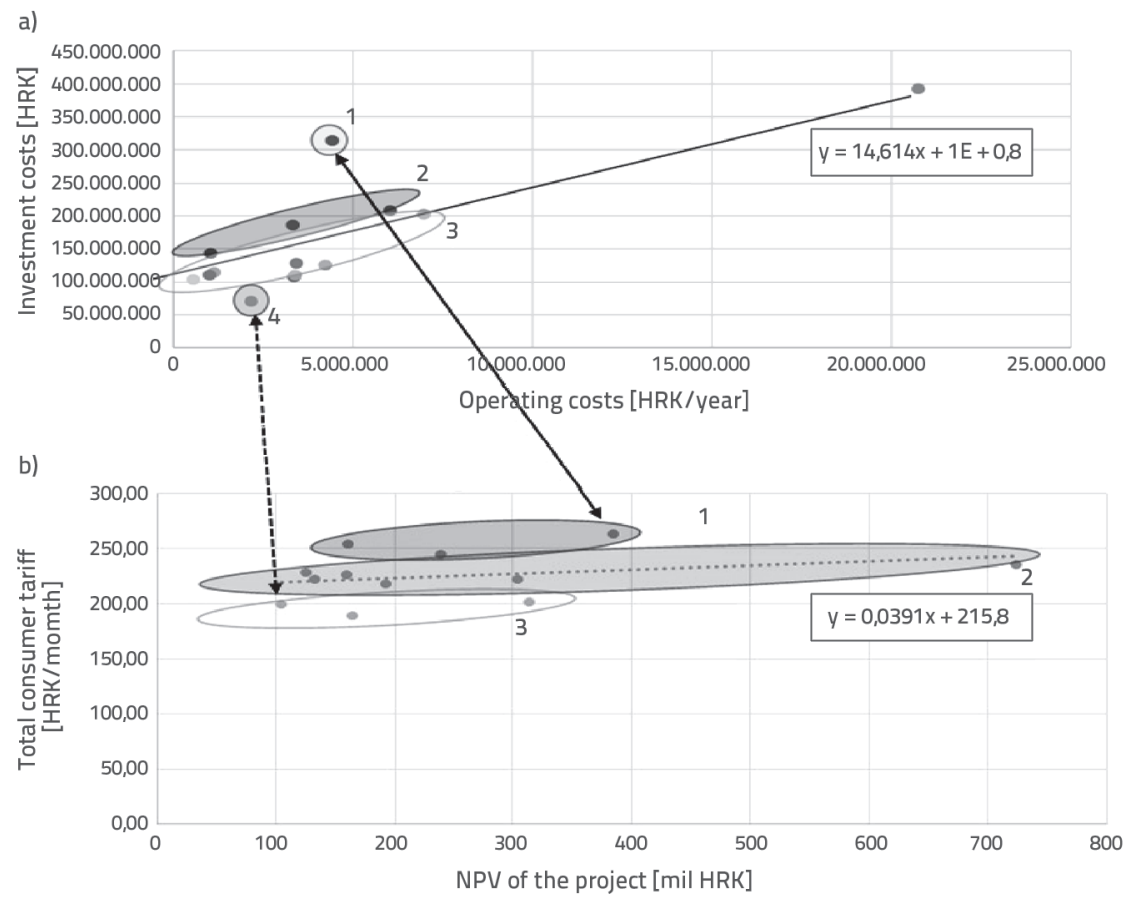

Figure 1. Comparison of: a) investment and operating costs; b) net present value and total consumer tariff on EU projects in continental Croatia (1 EUR = 7.5 HRK) 
distinctions between end-beneficiaries and their respective project scopes: some of them had a healthy amount of infrastructure built beforehand and did not need an extensive EU funded project, while others needed to completely build their infrastructure from the ground-up. By focusing on the total consumer tariff at the very end of the project period, it could be stated that every project is in its most ideal situation: fully built infrastructure for the intended scope and achieved planned connectivity. On the other hand, last year of the project period means that the depreciation of the project has been fully accounted for and any missteps in the investment size will be visible in the tariffs. For demonstration purposes, the NPV is shown in mill. HRK.

A number of conclusions can be drawn from both graphs, and by comparing the two. The following comments on the correlation of investment and operating costs (first graph) can be made:

- There is a general linear trend between investment and operating costs, as expected. A cluster of projects is located in the 100-200 mil. HRK, with one larger project amounting to almost 400 mil. HRK.

- As a rule of thumb, investment costs are generally well appraised since there is a clear unit-price correction mechanism through tendering procedures and contracts. Operating costs are subject to greater variation, and are heavily dependent on the consultant's estimate. Linear trend given can serve as an arbitrary border dividing underand over-estimated operating costs:

- Cluster marked 3 can be seen as appropriately estimated

- Cluster marked 2 can be seen as moderately undervalued in terms of operating costs

- Outlier marked 4 can be seen as moderately over-valued in terms of operating costs

- Outlier marked 1 can be seen as severely under-valued in terms of operating costs.

Regarding the correlation between the NPV and total consumer tariff, the following comments can be made (second graph):

- There is again a linear trend between NPV values and total consumer tariffs. The last project in question (NPV of 800 mill. HRK, total consumer tariff of around $250 \mathrm{HRK} /$ household/month) is the same as the last project shown in the trendline (400 mill. HRK of investment scope), which also happens to be the biggest urban area of the projects in question. Bigger urban areas generally require higher investment cost for EU projects due to their size, but bigger consumer base can "handle" the incremental cost of the project and the total consumer tariff. The slope of the presented trend mildly trends upwards, which leads to the conclusion that in continental Croatia the rule of thumb is the bigger the project, the larger the total consumer tariff, but not considerably so.

- Projects have been again divided into three groups, depending on their position in contrast to the trendline.
Cluster marked 1 can be seen as having too big total consumer tariffs at the end of the project period. There is a number of possible reasons: overvalued operating costs which lead to higher tariffs, over-pricing in the cost-benefit analysis, or excessively high existing consumer tariffs (before the project commencement) - current over-staffing or poor management of the utility company will surely reflect on the existing consumer tariffs.

Cluster marked 2 can be seen as appropriately measured in terms of consumer tariffs and project size.

Cluster marked 3 can be seen as having favourable consumer tariffs at the end of the project period. A couple of possible reasons are: on the negative side, undervalued operating costs will lead to smaller than necessary incremental boost of tariffs, or a poorly calculated depreciation of the project will minimize necessary tariff increase. On the positive side, a well-run utility company will have optimal existing consumer tariff and could easily handle the incremental boost in tariff, or a smaller (optimal) scope of the project will not result in a huge increase in the tariffs. No general conclusions can be made for the scenario of lower consumer tariffs, since the causes are clearly project-based.

Lastly, third set of comments can be made for cross-comparison of certain outliered projects:

- Outlier marked 4 (moderately over-valued operating costs) in the first graph correlates to one of the projects in cluster 3 (favourable consumer tariffs) of the second graph - this is outlined by the dashed line. This is counter-intuitive: if the operating costs are over-valued, should the tariff be overpriced? This means that either 1) the investment costs are under-valued, (2) cost-benefit analysis has undervalued consumer tariffs, or (3) the service has substantially low existing consumer tariffs. It is worth noting that the project in question is relatively small compared in NPV to others - statistically speaking, the results near the extremes are always less reliable. - Outlier marked 1 (severely under-valued operating costs) in the first graph correlates to one of the projects in cluster 1 (moderately high tariffs) of the second graph - this is outlined by the continuous line. This is once again counterintuitive: Assuming the correction of the operating costs, the planned tariffs would be even higher. This points to inevitable problems in the operational period of the project since these tariffs will probably be substantially higher than anticipated. The (probable) underlying cause is the over-expansion of the agglomeration scope to several rural areas, driving the operational costs up, while not achieving a sufficient number of new connections/customers.

It is worth noting that the final conclusions will be possible after at least 3-5 years following the project implementation, but it is the authors' opinion that the conclusion given above can be reached even now in the planning/tendering phase of the projects. 


\subsection{Coastal Croatia}

In the following section, an overview is given for $9 \mathrm{EU}$ projects in continental Croatia in various stages of development. Similar to coastal Croatia, general data have been extracted for all these projects, excluding investments into water supply and reconstruction/rehabilitation of the existing sewage network. Therefore, the scope of the projects has been exclusively oriented toward sewage extension (reflecting the proposed agglomeration size) and wastewater treatment.

There is a distinction that needs to be mentioned regarding preferred treatment technology. In coastal Croatia there is a more diverse choice of treatment technologies than in continental Croatia and, in the group of analysed EU projects, there are a number of projects which enlist more advanced technologies such as membrane bioreactor (MBR) plants and biological aerated filtration (BAF). These will have an impact on investment and operating costs and will make the comparison between projects somewhat less accurate. Additionally, since this area is heavily tourist oriented and geographically diverse, the number of agglomerations is bigger and the centralization of plants is in some places unfeasible to achieve. All this leads to a larger number of wastewater treatment plants, which also influenced the total costs of the projects.

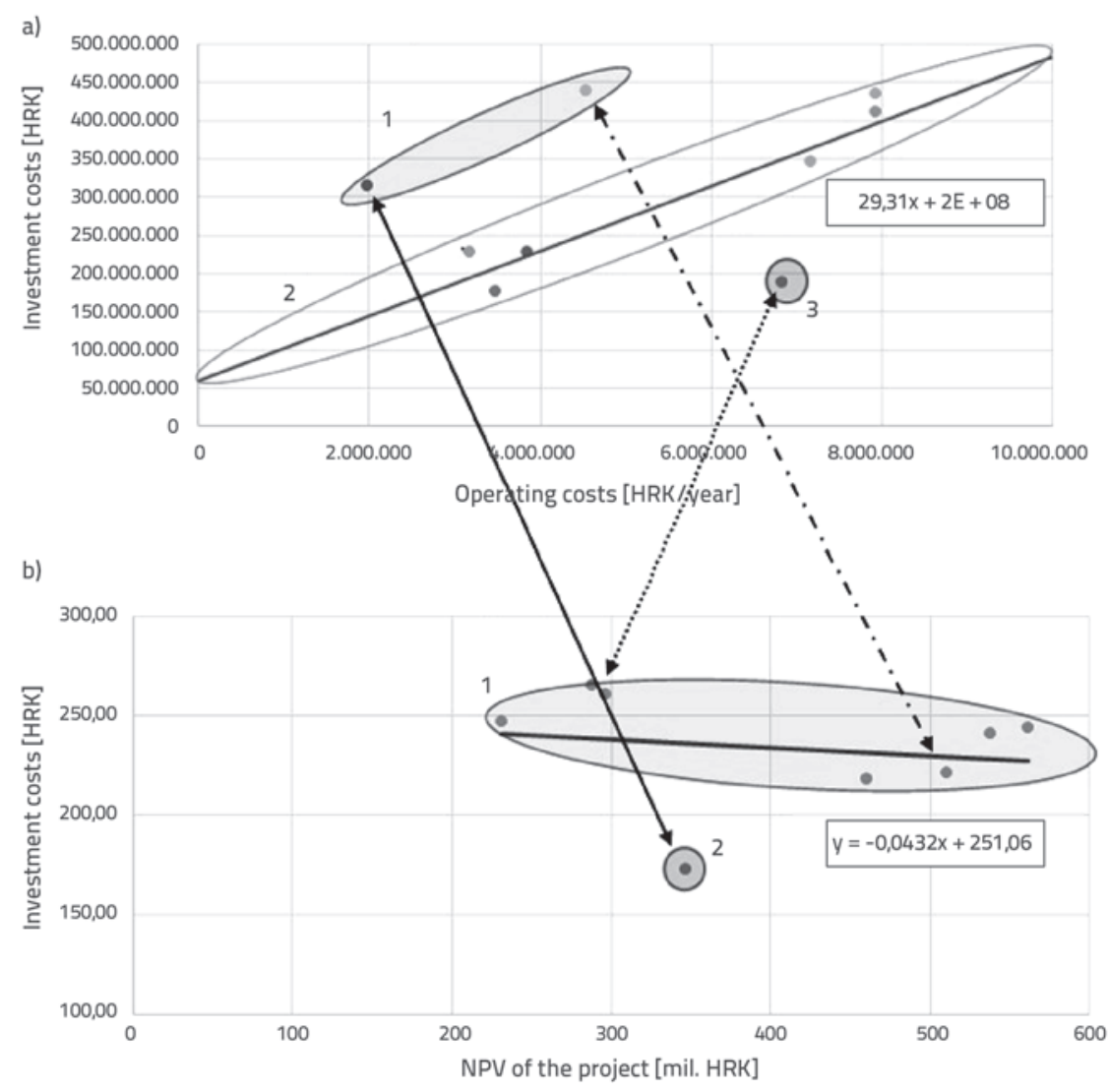

Figure 2. Comparison of: a) investment and operating costs; b) net present value and total consumer tariffs, on EU projects in coastal Croatia (1 EUR = 7.5 HRK)
It should be noted that all input preferences regarding calculation of NPV and total consumer tariffs, given for continental Croatia in Section 3.1, also apply to coastal Croatia.

A number of conclusions can be drawn from both graphs, and by comparing the two. The following comments can be made regarding the correlation of investment and operating costs (first graph):

There is a general linear trend between investment and operating costs, as could be expected. All projects are situated in the 150-400 mill. HRK range.

As a rule of thumb, investment costs are generally well appraised since there is a clear unit-price correction mechanism during tendering procedures and contracts. Operating costs are subject to more variation, depending on the consultant's estimate. Linear trend given can serve as an arbitrary border dividing under- and over-estimated operating costs.

- Cluster marked 1 can be seen as under-valued in terms of operating costs

- Cluster marked 2 can be seen as appropriately estimated

- Outlier marked 3 can be seen as over-valued in terms of operating costs

- As mentioned in the previous paragraph, since there is a diverse approach to treatment technology and general scope of projects in coastal Croatia, the results given above should take into account the respective characteristics of the projects. Detailed analysis of these projects is given in the "crosscomparison" section.

As seen in the previous example, statistical analysis of financial parameters for projects in coastal Croatia is seen as insufficient without examining the underlying components of the investment and operating costs, since there is host of exceptions from project to project.

The following comments regarding correlation between the NPV value and total consumer tariff can be made (second graph):

There is again a linear trend between NPV values and total consumer tariffs. The slope of the presented trend mildly trends downwards, a different trend compared to analysis made for projects situated in continental Croatia. The before mentioned thesis applies: bigger urban areas generally require higher investment costs for EU projects due to their size, but bigger consumer base can also handle the incremental cost of the project. However, bigger urban areas in coastal Croatia are also tourist hot-spots, 
and so the difference can be attributed to multiple consumer bases: tourism activity adds another consumer category that helps alleviate incremental operating costs and, overall, lowers the consumer tariff.

Projects were divided into two groups, depending on their position in contrast to the trend line.

a) Cluster marked 1 can be seen as appropriately measured in terms of consumer tariffs and project size.

b) Outlier marked 2 can be seen as having favourable consumer tariffs at the end of the project period.

Lastly, a third set of comments can be made for crosscomparison of certain outliers:

- Outlier marked 1 (under-valued operating costs) in the first graph correlates to the project in cluster 2 (favourable consumer tariffs) of the second graph - this is outlined by the continuous line. The project in question has no planned investment costs in WWTPs (only sewage extensions/ reconstructions) and, hence, the operating costs are lower. Lower operating costs lead in turn to lower tariffs and, after taking into account that the project in question is a major urban development, questionable low(er) tariffs are therefore explained through the combination of a large consumer base, strong touristic activity, and low planned project operation costs.

- Outlier marked 1 (under-valued operating costs) in the first graph correlates to the project in cluster 1 (appropriately estimated consumer tariffs) of the second graph - this is outlined by the dash-dotted line. The project in question consists of several WWTPs with advanced treatment technologies. This is counter-intuitive to the given premise (such project should have higher operating costs than expected and be located below the trend line in the tariff/ NPV graph). This means that there is almost surely a severe under-evaluation of the operating costs. Had it been appropriately valued for operating costs, it would have almost surely be situated distinctly above the trend line.

- Outlier marked 3 (over-valued operating costs) in the first graph correlates to the project in cluster 1 (appropriately estimated consumer tariffs, but in the higher range) of the second graph - this is outlined by the dotted line. This is deemed logical: higher operating costs lead to higher consumer tariffs, which is visible on both graphs. The project in question consists of a WWTP with advanced treatment technologies and a substantial incremental staffing costs, boosting overall operational costs. It can be concluded from the analysis of key financial parameters of the project that the project in question does not show any logical flaws.

Again, it is worth noting that the final conclusions will be possible after at least 3-5 years following project implementation, but it is the authors' opinion that the conclusion given above can be reached even now in the planning and/or construction phase of the projects.

\section{Conclusion}

The basis for any successful feasibility study is a detailed demand analysis highlighting important demographic, economic and technical parameters that result in an investment scope of the project. Apart from the input data, an equally important step is to accurately assess the agglomeration scope: the goal is to adequately define the agglomeration size to ensure fulfilment of the requirements of the Urban Waste Water Directive. Over-expansion of the agglomeration will surely lead to problems with the financial scope of the project: inadequate financial capability of the end-recipient, high investment and operating costs, and/ or (in)ability of the project area to sustain the increased consumer tariff.

Any missteps in project development can be observed through comparison of several key financial parameters. There should be a distinct correlation between investment and operating costs of the projects. Those two costs combined form the net present value of the project which can be linked to the total consumer tariff: the sole most important financial parameter of the feasibility study.

Fourteen EU funded projects in continental Croatia revealed general uniformity during assessment of investment and operating costs, with the notable exception of several outliers. Since the consumer base is highly uniform (permanent population and decreasing industry consumption) and the preferred treatment technologies are mostly similar, the outliers can only be attributed to over- and under-valuated operating costs - a clear error in the feasibility study. Total consumer tariffs are generally seen as appropriately valued with a couple of notable exceptions: excessively high tariffs are generally a sign of over-expansion of the planned agglomeration scopes, current over-staffing/poor management of the utility company, or the combination of both. The comparison of NPV and total consumer tariff showed that bigger projects tend to achieve slightly bigger tariffs than the smaller ones, but not considerably so. It is imperative to note that the agglomerations scope of the projects in continental Croatia need to be accurately assessed, because existing difficulties with average netincomes and decreasing water consumptions do not leave much room for tariff increase without triggering affordability issues.

Nine EU funded projects in coastal Croatia have a different set of underlying factors. Heavy touristic activity directly impacts the demand analysis and consumer structure. The agglomerations are subject to peak summer loads and so they grow in size. Additionally, there is a diversification of preferred treatment technologies, which influences the project comparison. All this leads to a higher margin of error. Several analysed outliers showed that the project distinctions heavily influenced overall results, and that no visible flaws regarding financial parameters were spotted. 
Other outliers were attributed to under-valuation of the operating costs, a mistake that can be linked to advanced treatment technologies. It can be concluded that there is a lack of experience in accurate assessment of cost with regard to advanced treatment technologies.

Still, certain trends have been spotted - the comparison of NPV and total consumer tariff showed that bigger projects tend to achieve slightly lower tariffs than the smaller ones. This was attributed to tourism activity - bigger urban areas will lead to bigger project scopes, but will also enlist higher consumer base which is heavily supported by tourist activity. This leads to a smaller total consumer tariff than for a non-tourist area. Consumer tariffs in coastal Croatia are on an average only $5 \%$ higher than in continental Croatia while benefiting from $60 \%$ bigger projects - which is yet another positive effect of tourism in coastal Croatia.

\section{REFERENCES}

[1] Direktiva o pročišćavanju komunalnih otpadnih voda (91/271 EEC), https://eur-lex.europa.eu/legal-content/HR/TXT/PDF/?ur $\mathrm{i}=$ CELEX:31991L0271\&from=HR，21.09.2017.

[2] Okvirna direktiva o vodama (2000/60/EC), https://eur-lex. europa.eu/legal-content/HR/TXT/PDF/?uri=CELEX:32000L006 0\&from=HR; 21.09.2017.

[3] Catalano G., Geno M., Pancotti C., Sirtori E., Vignetti S., Del Bo C.: Vodič kroz analizu troškova i koristi investicijskih projekata - Alat za ekonomsku procjenu kohezijske politike 2014-2020 prvo izdanje, Glavna uprava za regionalnu i urbanu politiku EU, prosinac 2014.

[4] Demografske projekcije za 28 članica Europske Unije, http:// appsso.eurostat.ec.europa.eu/nui/show.do?dataset=demo_ gind\&lang=en, 21.09.2017.

[5] Zakon o vodama (NN 153/09, 63/11, 130/11, 56/13, 14/14) 